\title{
The prevalence and social patterning of chronic diseases among older people in a population undergoing health transition. A 10/66 Group cross-sectional population-based survey in the Dominican Republic
}

Daisy Acosta', Ruth Rottbeck², Juana G Rodríguez³ , Loida M González4, Mary R Almánzar4, Susana N Minaya4, Maria del C Ortiz ${ }^{4}$, Cleusa P Ferri ${ }^{5}$ and Martin J Prince*5

\begin{abstract}
Background: Very little of the increased attention towards chronic diseases in countries with low and middle incomes has been directed towards older people, who contribute $72 \%$ of all deaths, and $14 \%$ of all Disability Adjusted Life Years linked to this group of conditions in those regions. We aimed to study the prevalence of physical, mental and cognitive diseases and impairments among older people in the Dominican Republic, their social patterning, and their relative contributions to disability.
\end{abstract}

Methods: A cross-sectional catchment area one-phase survey of chronic disease diagnoses, physical impairments, risk factors and associated disability among 2011 people aged 65 years and over (of whom 1451 gave fasting blood samples) in Santo Domingo, Dominican Republic.

Results: The most prevalent diagnoses were hypertension (73.0\%), anaemia (35.0\%), diabetes (17.5\%), depression (13.8\%) and dementia (11.7\%), with 39.6\% meeting criteria for metabolic syndrome. After direct standardization (for age and sex) the prevalences of stroke (standardized morbidity ratio [SMR] 100) and hypertension (SMR 108) were similar to those in the United States of America National Health and Nutrition Examination Survey (NHANES reference SMR 100), while those of diabetes (SMR 83) and metabolic syndrome (SMR 72) were somewhat lower. Anaemia was three times more common than in the USA (SMR 310). Diabetes, hypertension, dyslipidaemia, obesity and the metabolic syndrome were associated with affluence and female sex. Arthritis, anaemia, dementia and stroke were strongly age-associated and these conditions were also the main independent contributors to disability.

Conclusions: The prevalence of many chronic diseases is similar in predominately low socioeconomic status neighbourhoods in the Dominican Republic to that in the USA. Prevalence of age-associated conditions is likely to increase with demographic ageing. There is also scope for increases in cardiovascular disease prevalence, if, as observed in other settings undergoing the epidemiologic transition, the burden of risk factors shifts towards the less affluent. Monitoring future trends in the prevalence and social patterning of chronic diseases may help to assess the effectiveness and equity of primary and secondary prevention strategies. Specific recommendations from our research include identifying and targeting the causes of anaemia among older people, and addressing women's health disadvantages.

\footnotetext{
* Correspondence: martin.prince@kcl.ac.uk

5 Health Service and Population Research Department, Institute of Psychiatry P060, De Crespigny Park, London SE5 8AF, UK

Full list of author information is available at the end of the article
}

(C) 2010 Acosta et al; licensee BioMed Central Ltd. This is an Open Access article distributed under the terms of the Creative Commons :HW 1 ed Central Attribution License (http://creativecommons.org/licenses/by/2.0), which permits unrestricted use, distribution, and reproduction in any medium, provided the original work is properly cited. 


\section{Background}

With demographic ageing and the accompanying health transition, chronic diseases are assuming progressively greater significance in countries with low and middle incomes. They are already the leading cause of death in all world regions apart from sub-Saharan Africa. Of the 35 million chronic disease deaths in $2005,80 \%$ occurred in countries with low or middle incomes [1], partly because most of the world's older people live in these regions $-60 \%$ now rising to $80 \%$ by 2050 . However, changing patterns of risk exposure also contribute. Latin America exemplifies the third stage of health transition. As life expectancy improves, and high fat diets, cigarette smoking and sedentary lifestyles become more common, so cardiovascular diseases have maximum public health salience - more so than in stage two regions (China and India) where risk exposure is not yet so elevated, and in stage four regions (Europe) where public health measures have reduced exposure levels [2]. The INTERHEART cross-national case-control study suggests that risk factors for myocardial infarction operate equivalently in all world regions, including Latin America [3].

In a bibliometric analysis of low and middle income country journals covering the period 1998-2003 more than $40 \%$ of articles focused on chronic disease research, cardiovascular diseases and cancers being the most popular topics [4]. However, the Latin American region was underrepresented. Chronic disability and its determinants have received comparatively little attention, in research, policy or practice. While cardiovascular diseases and cancers contribute mainly to mortality, much of the burden of other chronic diseases (dementia, mental disorders, diabetes and stroke) arises from years lived with disability [5]. Despite the growing interest in chronic diseases in low and middle income countries [6,7], there is limited information available on their prevalence and impact, and most comprehensive studies focus exclusively or mainly upon young and middle-aged adults [810]. Older people contribute $72 \%$ of all deaths [5], and $14 \%$ of all years lived with disability linked to chronic diseases in low and middle income countries.

Health policy should be informed by precise estimates of disease prevalence and burden. These are lacking for most chronic diseases in most countries with low and middle incomes, particularly for older adults. The 10/66 Dementia Research Group studies in seven Latin American countries, India and China aim to chart the progress of the health transition and its impact upon older persons [11]. This report, from the Dominican Republic, is a comprehensive population-based study of the prevalence and social patterning of chronic disease diagnoses, risk factors and impairments among older people, and their contribution to disability.

\section{Methods}

Setting

The Dominican Republic shares the Caribbean island of Hispaniola with Haiti. The population is 9.4 million, and 0.5 million (5.7\%) are aged 65 and over [12]. Life expectancy is 71 years for men and 75 for women. It is one of the poorest and most unequal of Latin American countries. The per capita GDP (purchasing power parity) is US\$ 9,200; $42 \%$ of the population live below the poverty line, one third of whom in extreme poverty. Pension coverage, at only $18 \%$ of the economically active population, is one of the lowest in Latin America. Community health care is provided by the government through 'primary attention units'. Consultations are free, but medicines must be paid for. Despite low medical insurance coverage, private healthcare is widely patronised.

\section{Study design and catchment area}

A one-phase cross-sectional whole population catchment area survey of all those aged 65 years and over in geographically defined districts in Santo Domingo. Ethical approval for the survey was provided by the research ethics committee for the Institute of Psychiatry, King's College London, and the Bioethics National Committee for Research in the Dominican Republic. Precision calculations indicated that a sample of 2,000 would allow estimation of a dementia prevalence of $2.5 \%$ with a precision of $\pm 0.9 \%$. Catchment area sites were selected purposively, middle-class or high-income areas were avoided. The catchment areas selected were Villa Francisca, San Carlos, San Antón, Mejoramiento Social and Santa Barbara. After defining boundaries, mapping was carried out to identify and locate households. All eligible participants (inclusion criterion age 65 and over) were identified and invited to participate. Age was formally determined on revisit for the interview. Participants were recruited following informed consent or on the basis of a relative's agreement in case of lack of capacity for consent due to dementia. Interviews were carried out in participants' own homes. All participants received the full assessment lasting approximately two to three hours. Ethical approval for the survey was provided by the King's College London research ethics committee, and the Bioethics National Committee for Research in the Dominican Republic.

\section{Measures}

The components of the 10/66 Dementia Research Group baseline population-based survey protocol $[11,13]$ that are relevant to this paper are:

1) a structured clinical mental state interview, the Geriatric Mental State, which applies a computer algorithm (Automated Geriatric Examination for Computer Assisted Taxonomy - AGECAT) [14], identifying organic- 
ity (probable dementia), depression, anxiety and psychosis

2) a cognitive test battery comprising the Community Screening Instrument for Dementia (CSI'D') COGSCORE [15] incorporating the Consortium to Establish a Registry for Alzheimer's Disease (CERAD) animal naming verbal fluency task, and the modified CERAD 10 word list learning task with delayed recall [16]

3) The CSI'D' informant interview [15], for evidence of cognitive and functional decline

4) a participant health and risk factor interview covering self-reported diagnoses (including diabetes, stroke, heart attack, angina and hypertension), impairments and disability

5) a fasting blood sample analysed for lipids, glucose and haemoglobin (Sysmex K800 hematology autoanalyser)

6) a physical examination, including systolic and diastolic blood pressure (the mean of two sitting assessments) and anthropometry

Information from these assessments was used to identify describe health states (diagnoses, impairments and risk factors), as follows:

\section{Diagnoses}

a) Dementia according to either the 10/66 dementia diagnosis algorithm [17] or Diagnostic and Statistical Manual of Mental Disorders, 4th. Edition (DSM-IV) dementia criterion [18].

b) Depression - International Classification of Diseases $10^{\text {th }}$ revision (ICD-10) depressive episode (mild, moderate or severe), ascertained using the Geriatric Mental State [14].

c) Self-reported stroke, angina and myocardial infarction (an answer of 'yes' to the questions "have you ever been told by a doctor that you had a stroke/heart attack/ angina?")

d) Chronic obstructive pulmonary disease, defined as having a chronic cough, productive of sputum for three or more months

e) Diabetes - either a self-reported diagnosis of diabetes (an answer of 'yes' to the question "have you ever been told by a doctor that you have diabetes?"), and/or a blood glucose of $>7 \mathrm{mmol} / \mathrm{l}$ from the survey fasting blood sample

f) Hypertension - either a self-reported diagnosis of hypertension, currently under treatment (an answer of "yes" to the question "have you ever been told that you have raised blood pressure?" and "yes" to the questions "were you started on treatment?" and "are you still on treatment?") and/or meeting World Health Organization/ International Society of Hypertension criteria (systolic blood pressure $>=140 \mathrm{~mm} \mathrm{Hg}$ and/or diastolic blood pressure $>=90 \mathrm{~mm} \mathrm{Hg}$ on current survey examination. g) Anaemia - defined as haemoglobin < $12 \mathrm{~g} / \mathrm{dl}$ for women and $13 \mathrm{~g} / \mathrm{dl}$ for men

\section{Physical impairments}

Self-reported arthritis or rheumatism; eyesight problems; hearing difficulty or deafness; persistent cough; breathlessness, difficulty breathing or asthma; high blood pressure; heart trouble or angina; stomach or intestine problems; faints or blackouts; paralysis, weakness or loss of one leg or arm; skin disorders (pressure sores, leg ulcers or burns) [19]. Each impairment was rated as present if it interfered with activities 'a little' or 'a lot'.

\section{Disability}

Activity limitation and participation restriction measured by the World Health Organization Disability Assessment Schedule (WHODAS 2.0) [20], developed as a culturefair assessment tool for use in cross-cultural comparative epidemiological and health services research. Disability days were also ascertained and dichotomised at 15 or more days in the last month, to indicate severe disability.

\section{Risk factors}

a) Metabolic syndrome according to the criteria proposed by the Third Report of the National Cholesterol Education Program: presence of three or more of the following;

1. Central obesity as measured by waist circumference: Men $>40$ inches, Women $>35$ inches.

2. Fasting triglycerides $>=150 \mathrm{mg} / \mathrm{dL}$.

3. HDL cholesterol: Men < $40 \mathrm{mg} / \mathrm{dL}$, Women < $50 \mathrm{mg} /$ $\mathrm{dL}$ (Cholesterol subfractions were not analysed, so we have instead substituted the criterion of total cholesterol $>=5.2 \mathrm{mmol}$ )

4. Blood pressure $>=130 / 85 \mathrm{mmHg}$.

5. Fasting glucose $>=110 \mathrm{mg} / \mathrm{dL}$

b) alcohol use (hazardous drinking currently, and before the age of 60),

c) lifetime smoking - 20 or more pack years of lifetime exposure

d) self-reported exercise - taking no walks of 500 metres or more in the past month

\section{Analyses}

1) We report the prevalence of each health state by age and sex using Stata 9.2 survey commands to generate robust standard errors and $95 \%$ confidence intervals, taking account of household clustering. We used indirect standardization (by age, or sex, or age and sex as feasible) to compare our prevalence estimates for diabetes, hypertension, metabolic syndrome, stroke and anaemia with those from the United States National Health and Nutrition Examination Survey (NHANES) [21-25], and for dementia with those from the EURODEM consortium European meta-analysis [26], calculating standardized morbidity ratios with $95 \%$ confidence intervals 
2) We describe the association between age in years and each health state, controlling for sex, and the association with sex controlling for age in years. We also report the association between socioeconomic position indicated by quarters of household assets controlling for age in years and sex. For these analyses we used Poisson regression working models to generate prevalence ratios, adjusted for household clustering.

3) We describe independent associations between diagnoses and impairments and disability using zero inflated binomial regression for the WHODAS total score (correcting for zero inflation and overdispersion) and Poisson regression for the dichotomous outcome of 15 or more disability days in the last month. The resulting prevalence ratios, together with the prevalence of the exposures (diagnoses and impairments were used to calculate population attributable prevalence fractions using the STATA aflogit command, as an index of the salience of each health condition to the prevalence of severe disability at the population level.

\section{Results \\ Sample characteristics}

Door-knocking of the five catchment areas yielded 2117 persons eligible for the study; 2011 (95\%) provided informed consent and were interviewed. Of these 1483 (74\%) provided fasting blood samples. The principal characteristics of the participants are provided in Table 1. Their median age was 74 years (interquartile range 69 to 80 years, total range 65 to 104 years). Two thirds of the participants were female (65.9\%). The large majority (71.0\%) had not completed primary education. Living alone was unusual (12.6\%); most lived in two to four person households. A high proportion of participants were separated or divorced (23.1\%), with only $29.1 \%$ currently married. Those providing blood samples were more likely to be female ( $68 \%$ vs. $60 \%)$, depressed ( $15 \%$ vs. $11 \%)$, there were no differences in age, education, household assets, blood pressure levels or dementia diagnoses.

\section{Prevalence of diagnoses and impairments}

The most prevalent chronic disease diagnoses were hypertension $(73.0 \%)$, anaemia $(35.0 \%)$, diabetes $(17.5 \%)$, depression (13.8\%) and dementia (11.7\%). Cardiovascular diseases; stroke (8.7\%), myocardial infarction (1.7\%) and angina (1.2\%) were less common (Table 2). The most prevalent organ and system impairments were eyesight problems (39.6\%), arthritis or rheumatism (36.7\%), stomach or intestine problems (19.3\%) and hearing problems (12.7\%). Respiratory problems, heart trouble, limb problems, faints or blackouts and skin disorders all had a prevalence of $10 \%$ or less (Table 3). Standardizing for age and sex, the prevalence of anaemia was more than three times higher than that in the United States of America, (Table 4). Dementia and stroke prevalences were similar to those recorded in Europe and the United States of America respectively. The prevalence of diabetes and metabolic syndrome were somewhat lower, and that of hypertension slightly higher than in the United States of America.

\section{The effects of age and sex}

Controlling for sex, the prevalence of dementia, stroke, anaemia and depression increased with age, while that of diabetes was lower among older participants (Table 5). Among the impairments, the prevalence of eyesight and hearing problems, cough, limb problems and skin disorders all increased with age, as did overall disability (Table 6). Regarding risk factors, the prevalence of dyslipidaemia, metabolic syndrome and smoking declined with increasing age (Tables 7 and 8). Inactivity increased with age. Controlling for age, stroke and anaemia were more common in men, while hypertension and depression were more common in women (Table 5). Most impairments; arthritis, eyesight problems, stomach or intestine problems, faints or blackouts were more common in women, who were also more likely to report 15 or more disability days (Table 6). Most cardiovascular risk factors; dyslipidaemia, obesity, hyperglycaemia, inactivity, and the metabolic syndrome were also more common among women (Table 8). Smoking, however, was considerably more common among men.

\section{The effect of socioeconomic position}

Controlling for age and sex, dementia, chronic obstructive pulmonary disease, anaemia and depression were each less prevalent with increasing household assets (Table 5). The association was in the opposite direction for diabetes, hypertension, dyslipidaemia, obesity, hyperglycaemia and the metabolic syndrome (Tables 5 and 8). There was a trend for all physical impairments to be inversely associated with assets, statistically significant for eyesight problems, cough, breathing difficulties, faints or blackouts and skin disorders (Table 6). Disability was also strongly inversely associated with assets. We also tested for associations with level of education (detailed results available on request). None of the health conditions positively associated with assets (diabetes, hypertension, dyslipidaemia, obesity, hyperglycaemia and the metabolic syndrome) was associated with higher levels of education. However, most of the conditions negatively associated with household assets were also negatively associated with level of education (dementia, anaemia and depression). There were only non-significant trends towards negative associations between educational level and individual impairments, but there was a significant inverse association with disability. 
Table 1: Sociodemographic and (selected) health characteristics of the sample, and the sub-groups for whom blood samples were, and were not taken

\begin{tabular}{|c|c|c|c|c|}
\hline $\begin{array}{l}\text { Characteristics (number and \% unless } \\
\text { otherwise stated) }\end{array}$ & $\begin{array}{l}\text { Whole sample } \\
(\mathrm{n}=\mathbf{2 0 1 1})\end{array}$ & $\begin{array}{l}\text { Blood sample taken } \\
(n=1451)\end{array}$ & $\begin{array}{l}\text { Blood sample not taken } \\
(n=560)\end{array}$ & $\begin{array}{l}\text { Statistical test comparing } \\
\text { sub-groups with and } \\
\text { without blood samples }\end{array}$ \\
\hline Age median ( $25^{\text {th }}$ and $75^{\text {th }}$ centiles) & $74(69-80)$ & $74(69-81)$ & $74(69-80)$ & $Z=-1.46, p=0.14$ \\
\hline Female sex & $1324(65.9 \%)$ & $316(60.0 \%)$ & $1008(68.0 \%)$ & $X^{2}=11.2, p=0.001$ \\
\hline \multicolumn{5}{|l|}{ Education $\left(\mathrm{MV}^{1}=19\right)$} \\
\hline None & $392(19.7 \%)$ & $98(18.8 \%)$ & $294(20.0 \%)$ & $X^{2}=0.8, p=0.39$ \\
\hline Some & $1022(51.3 \%)$ & $268(51.5 \%)$ & $754(51.2 \%)$ & \\
\hline Completed primary & $370(18.6 \%)$ & 97 (18.7\%) & $273(18.5 \%)$ & \\
\hline Secondary or tertiary & $208(10.5 \%)$ & $57(11.0 \%)$ & $151(10.3 \%)$ & \\
\hline Living alone & $254(12.6 \%)$ & $79(15.0 \%)$ & $175(11.8 \%)$ & $X^{2}=3.5, p=0.06$ \\
\hline \multicolumn{5}{|l|}{ Marital status $(\mathrm{MV}=15)$} \\
\hline Never married & $139(7.0 \%)$ & $44(8.4 \%)$ & $95(6.5 \%)$ & $X^{2}=4.8, p=0.19,3 \mathrm{df}$ \\
\hline Divorced/separated & $465(23.1 \%)$ & $133(25.4 \%)$ & $332(22.6 \%)$ & \\
\hline Widowed & $806(40.4 \%)$ & $198(37.8 \%)$ & $608(41.3 \%)$ & \\
\hline Currently married & $586(29.1 \%)$ & $149(28.45)$ & $437(29.7 \%)$ & \\
\hline \multicolumn{5}{|l|}{ Assets } \\
\hline $0-4$ & $648(32.2)$ & $167(31.6 \%)$ & $481(32.4 \%)$ & $X^{2}=0.3, p=0.58$ \\
\hline 5 & $444(22.1)$ & $115(21.8 \%)$ & $329(22.2 \%)$ & \\
\hline 6 & $733(36.4)$ & $194(36.7 \%)$ & $539(36.3 \%)$ & \\
\hline 7 & $186(9.2 \%)$ & $52(9.8 \%)$ & $134(9.0 \%)$ & \\
\hline Three or more limiting illnesses $(\mathrm{MV}=2)$ & $465(23.1 \%)$ & $115(21.8 \%)$ & $350(23.6 \%)$ & $X^{2}=0.7, p=0.40$ \\
\hline Depression & $278(13.8 \%)$ & $56(10.6 \%)$ & $222(15.0 \%)$ & $x^{2}=6.2, p=0.01$ \\
\hline Dementia & $235(11.7 \%)$ & $68(12.9 \%)$ & $167(11.3 \%)$ & $X^{2}=1.0, p=0.32$ \\
\hline Systolic blood pressure mean (SD) $(\mathrm{MV}=20)$ & $136.2(20.1)$ & $136.3(20.6)$ & $136.2(20.0)$ & $F=0.56, p=0.97,1989$ \\
\hline Waist circumference mean $(S D)(M V=25)$ & $92.3(12.9)$ & $91.6(13.6)$ & $92.5(12.6)$ & $F=0.53, p=0.18,1984$ \\
\hline
\end{tabular}




\section{Associations with disability}

In order of level of contribution, defined by the population attributable prevalence fraction, the strongest independent influences upon disability were arthritis, anaemia, limb impairments, dementia, depression, intestinal problems and stroke (Table 9). None of the indicators of ischaemic heart disease or respiratory impairment was significantly associated with disability.

\section{Discussion}

In the current study we were able to ascertain the prevalence and distribution of a wide range of chronic disease diagnoses, impairments and underlying risk factors in a large population-based sample drawn from urban catchment areas in Santo Domingo, the capital city of the Dominican Republic. There have been very few previous reports of the prevalence of chronic diseases and their risk factors among older people, in countries with low and middle incomes in Latin America or other regions. In our study, the catchment areas were selected as typical examples of the lower income areas that account for much of Santo Domingo's population. However, findings from this survey cannot be generalised safely to other parts of the city or to the country as a whole. Not all diagnoses were ascertained with equivalent rigour; selfreported clinician diagnoses, for example stroke and heart disease, may have been under-reported with respect to other conditions such as dementia and depression that were identified through clinical interview, and hypertension and diabetes that were identified through blood pressure and fasting glucose measurement respectively. The overall proportion responding, 95\%, was very high. However, only $74 \%$ of those agreeing to the survey also supplied fasting blood samples that were used to identify diabetes, hyperlipidaemia, metabolic syndrome and anaemia. While most sociodemographic and health variables were not associated with provision of a blood sample, women, depressed participants, and those with three or more limiting impairments were slightly overrepresented among those giving blood samples suggesting some potential for non-response bias in the estimation of the prevalence and correlates of these metabolic and haematological disorders.

In the CARMELA study of cardiovascular risk in those aged 25-64 years in seven Latin American cities [8], the prevalences of hypertension, diabetes and metabolic syndrome were similar to developed countries in Venezuela, Argentina and Chile with a lower prevalence in the less developed Latin American countries. The Dominican Republic is just 90 minutes flying time from Miami but purchasing power parity per capita gross domestic product is only one fifth that of the United States of America $(\$ 9,200$ versus $\$ 46,000)$. Demographic ageing is much less advanced in the Dominican Republic, with just $5.7 \%$ of its population aged 65 and over, compared with $12.6 \%$ in the United States of America. Nevertheless, the age and sex adjusted prevalence of dementia and stroke seem already to have reached levels seen in Europe and the United States of America. Hypertension is, if anything, slightly more prevalent in the Dominican Republic. The high prevalence of hypertension and stroke may be explained in part by the high levels of African racial admixture seen in many residents of our catchment areas. Only diabetes and the metabolic syndrome were marginally less prevalent than in the United States of America. At the same time, anaemia, a condition strongly linked to dietary deficiency and poverty is more than three times more common in the Dominican Republic. This pattern of morbidity illustrates the 'double burden' of disease in countries undergoing the health transition - as chronic diseases become more prevalent, infectious and nutritional disorders recede but continue to make important contributions to mortality and disability.

Predicting the impact of the demographic and health transitions requires an understanding of the influences of age, sex and socioeconomic status on disease frequency and underlying risk factor exposures. In the Dominican Republic the negative relationship with increasing age for all cardiovascular risk factors other than hypertension suggests either a cohort effect with increasing exposure levels to be anticipated in future aged cohorts, or selective mortality, in which case improved secondary prevention may lead over time to more chronic morbidity and disability. Most of the disorders that were positively associated with older age (arthritis, anaemia, dementia, stroke, limb impairments) also made strong independent contributions to disability. Thus, in this setting, the numbers of frail and dependent older persons are likely to increase rapidly with demographic ageing. We have previously shown that the age-specific prevalence of dependence in the Dominican Republic is already similar to that in developed nations [27]. Unfortunately, social protection for older people in the Dominican Republic is very poorly developed. Pension coverage has been among the poorest in the world. Our survey indicated a particularly high proportion of older people without children available to care [28], both because of infertility and outmigration.

In the United States of America, the age-adjusted prevalence of hypertension [29], diabetes [21] and the metabolic syndrome [22] is similar in men and women. However, women with diabetes and hypertension may be at greater risk of cardiovascular disease [30]. The prevalence of metabolic syndrome in the Dominican Republic was double in older women that of men, mainly due to a marked excess of obesity and dyslipidaemia among women, and a trend towards a higher prevalence of diabetes. This is consistent with findings among younger 
Table 2: Prevalence of Diagnoses by Age and Sex

\begin{tabular}{|c|c|c|c|c|c|c|}
\hline \multirow[b]{2}{*}{ Diagnoses } & \multirow[b]{2}{*}{ Sex } & \multicolumn{5}{|c|}{ Prevalence of diagnoses by age and sex (\% with $95 \%$ confidence intervals) } \\
\hline & & $\begin{array}{l}65-69 \\
N=533\end{array}$ & $\begin{array}{l}70-74 \\
N=520\end{array}$ & $\begin{array}{l}75-79 \\
N=397\end{array}$ & $\begin{array}{l}80+ \\
N=561\end{array}$ & $\begin{array}{l}\text { All } \\
N=2011\end{array}$ \\
\hline \multirow[t]{2}{*}{$\begin{array}{l}\text { Dementia } \\
\text { (10/66 criterion) }\end{array}$} & $\mathrm{F}$ & $\begin{array}{l}3.5 \\
1.6,5.4\end{array}$ & $\begin{array}{l}7.1 \\
4.3,9.9\end{array}$ & $\begin{array}{l}11.7 \\
7.8,15.5\end{array}$ & $\begin{array}{l}25.5 \\
21.2,29.8\end{array}$ & $\begin{array}{l}12.5 \\
10.8,14.3\end{array}$ \\
\hline & M & $\begin{array}{l}4.8 \\
1.7,7.8\end{array}$ & $\begin{array}{l}6.1 \\
2.8,9.5\end{array}$ & $\begin{array}{l}14.5 \\
8.5,20.5\end{array}$ & $\begin{array}{l}17.2 \\
11.5,22.9\end{array}$ & $\begin{array}{l}10.1 \\
7.8,12.3\end{array}$ \\
\hline Stroke & $\mathrm{F}$ & $\begin{array}{l}4.7 \\
2.4,6.9\end{array}$ & $\begin{array}{l}9.0 \\
5.9,12.1\end{array}$ & $\begin{array}{l}5.3 \\
2.6,7.9\end{array}$ & $\begin{array}{l}10.7 \\
7.7,13.8\end{array}$ & $\begin{array}{l}7.6 \\
6.2,9.1\end{array}$ \\
\hline $\mathrm{MV}^{1}=6$ & M & $\begin{array}{l}9.0 \\
4.9,13.1\end{array}$ & $\begin{array}{l}13.8 \\
8.9,18.6\end{array}$ & $\begin{array}{l}7.6 \\
3.1,12.2\end{array}$ & $\begin{array}{l}11.9 \\
7.0,16.8\end{array}$ & $\begin{array}{l}10.8 \\
8.5,13.2\end{array}$ \\
\hline Myocardial infarction & $\mathrm{F}$ & $\begin{array}{l}1.7 \\
0.4,3.1\end{array}$ & $\begin{array}{l}2.2 \\
0.6,3.8\end{array}$ & $\begin{array}{l}2.3 \\
0,5,4.0\end{array}$ & $\begin{array}{l}1.5 \\
0.3,2.7\end{array}$ & $\begin{array}{l}1.9 \\
1.2,2.6\end{array}$ \\
\hline $\mathrm{MV}=35$ & M & $\begin{array}{l}1.6 \\
0.0,3.4\end{array}$ & $\begin{array}{l}1.5 \\
0.0,3.3\end{array}$ & $\begin{array}{l}1.5 \\
0.0,3.6\end{array}$ & $\begin{array}{l}1.2 \\
0.0,2.8\end{array}$ & $\begin{array}{l}1.5 \\
0.6,2.4\end{array}$ \\
\hline Angina & $\mathrm{F}$ & $\begin{array}{l}1.2 \\
0.0,2.3\end{array}$ & $\begin{array}{l}2.2 \\
0.6,3.8\end{array}$ & $\begin{array}{l}0.4 \\
0.0,1.1\end{array}$ & $\begin{array}{l}1.3 \\
0.2,2.4\end{array}$ & $\begin{array}{l}1.3 \\
0.7,1.9\end{array}$ \\
\hline $\mathrm{MV}=25$ & M & $\begin{array}{l}1.1 \\
0.0,2.5\end{array}$ & $\begin{array}{l}0.5 \\
0.0,1.5\end{array}$ & $\begin{array}{l}1.5 \\
0.0,3.6\end{array}$ & $\begin{array}{l}1.8 \\
0.0,3.8\end{array}$ & $\begin{array}{l}1.2 \\
0.4,2.0\end{array}$ \\
\hline Chronic obstructive pulmonary disease & $\mathrm{F}$ & $\begin{array}{l}6.1 \\
3.6,8.7\end{array}$ & $\begin{array}{l}7.1 \\
4.3,9.9\end{array}$ & $\begin{array}{l}6.0 \\
3.2,8.9\end{array}$ & $\begin{array}{l}5.6 \\
3.3,7.9\end{array}$ & $\begin{array}{l}6.2 \\
4.9,7.5\end{array}$ \\
\hline$M V=3$ & M & $\begin{array}{l}6.4 \\
2.9,9.9\end{array}$ & $\begin{array}{l}6.6 \\
3.1,10.1\end{array}$ & $\begin{array}{l}9.9 \\
4.8,15.0\end{array}$ & $\begin{array}{l}10.1 \\
5.6,14.7\end{array}$ & $\begin{array}{l}8.1 \\
6.0,10.1\end{array}$ \\
\hline $\begin{array}{l}\text { Hypertension (meets ISH criteria, and/or currently on } \\
\text { treatment) }\end{array}$ & $\mathrm{F}$ & $\begin{array}{l}71.0 \\
66.2,75.8\end{array}$ & $\begin{array}{l}76.4 \\
71.8,81.0\end{array}$ & $\begin{array}{l}75.2 \\
70.0,80.3\end{array}$ & $\begin{array}{l}77.6 \\
73.4,81.8\end{array}$ & $\begin{array}{l}75.1 \\
72.7,77.5\end{array}$ \\
\hline$M V=13$ & M & $\begin{array}{l}67.7 \\
61.1,74.4\end{array}$ & $\begin{array}{l}72.2 \\
65.9,78.5\end{array}$ & $\begin{array}{l}68.2 \\
60.2,76.3\end{array}$ & $\begin{array}{l}67.3 \\
60.1,74.5\end{array}$ & $\begin{array}{l}69.0 \\
65.5,72.5\end{array}$ \\
\hline \multirow[t]{2}{*}{$\begin{array}{l}\text { Diabetes (self-reported diagnosis and/or blood glucose } \\
\text { of }>7 \mathrm{mmol} / \mathrm{l} \text { ) }\end{array}$} & $\mathrm{F}$ & $\begin{array}{l}20.5 \\
15.7,25.4\end{array}$ & $\begin{array}{l}22.2 \\
17.0,27.3\end{array}$ & $\begin{array}{l}15.3 \\
10.3,20.2\end{array}$ & $\begin{array}{l}15.6 \\
11.4,19.8\end{array}$ & $\begin{array}{l}18.4 \\
16.0,20.9\end{array}$ \\
\hline & M & $\begin{array}{l}20.5 \\
13.6,27.3\end{array}$ & $\begin{array}{l}16.5 \\
10.2,22.9\end{array}$ & $\begin{array}{l}14.4 \\
7.2,21.7\end{array}$ & $\begin{array}{l}10.1 \\
4.7,15.5\end{array}$ & $\begin{array}{l}15.6 \\
12.3,18.9\end{array}$ \\
\hline Anaemia & $\mathrm{F}$ & $\begin{array}{l}30.7 \\
25.1,36.2\end{array}$ & $\begin{array}{l}25.5 \\
20.0,31.0\end{array}$ & $\begin{array}{l}38.8 \\
32.1,45.6\end{array}$ & $\begin{array}{l}39.0 \\
33.4,44.6\end{array}$ & $\begin{array}{l}33.4 \\
30.5,36.3\end{array}$ \\
\hline$M V=10$ & M & $\begin{array}{l}28.8 \\
21.1,36.5\end{array}$ & $\begin{array}{l}31.8 \\
23.9,39.8\end{array}$ & $\begin{array}{l}40.0 \\
29.9,50.1\end{array}$ & $\begin{array}{l}54.6 \\
45.7,63.6\end{array}$ & $\begin{array}{l}38.3 \\
33.8,42.7\end{array}$ \\
\hline \multirow[t]{2}{*}{ ICD-10 depression } & $\mathrm{F}$ & $\begin{array}{l}14.0 \\
10.3,17.7\end{array}$ & $\begin{array}{l}13.9 \\
10.1,17.8\end{array}$ & $\begin{array}{l}16.2 \\
11.7,20.6\end{array}$ & $\begin{array}{l}16.8 \\
13.1,20.5\end{array}$ & $\begin{array}{l}15.3 \\
13.2,17.2\end{array}$ \\
\hline & M & $\begin{array}{l}8.5 \\
4.5,12.4\end{array}$ & $\begin{array}{l}6.6 \\
3.1,10.1\end{array}$ & $\begin{array}{l}16.0 \\
9.7,22.3\end{array}$ & $\begin{array}{l}15.4 \\
9.9,20.8\end{array}$ & $\begin{array}{l}11.1 \\
8.7,13.4\end{array}$ \\
\hline
\end{tabular}

1. $M V=$ missing values

Latin Americans [8], but contrasts with the higher prevalence among men in many developed country studies, albeit that recent increases in prevalence have been more rapid among younger women [30]. In our study, older women were also more likely to have been diagnosed as hypertensive, but were generally better controlled. Despite the generally increased cardiovascular risk exposure among women, the prevalence of stroke was markedly higher among men in all age groups and there was little effect of sex on ischemic heart disease. The very low levels of smoking among women may have compensated.

Our most striking findings relate to health inequalities. In countries with high incomes, cardiovascular risk factors and diseases are typically associated with poverty. Our assessment of the effects of the effects of socioeconomic position on chronic disease outcomes may have been limited to some extent by the constrained variance in the predominately low social class catchment areas. 
Table 3: Prevalence of Impairments and Disability by Age and Sex

\begin{tabular}{|c|c|c|c|c|c|c|}
\hline \multirow[t]{2}{*}{ Impairments and disability } & \multirow[b]{2}{*}{ Sex } & \multicolumn{5}{|c|}{ Prevalence of impairments by age and sex (\% with $95 \%$ confidence intervals) } \\
\hline & & $\begin{array}{l}65-69 \\
N=533\end{array}$ & $\begin{array}{l}70-74 \\
N=520\end{array}$ & $\begin{array}{l}75-79 \\
N=397\end{array}$ & $\begin{array}{l}80+ \\
N=561\end{array}$ & $\begin{array}{l}\text { All } \\
N=2011\end{array}$ \\
\hline Arthritis or rheumatism & $\mathrm{F}$ & $\begin{array}{l}42.6 \\
37.3,47.8\end{array}$ & $\begin{array}{l}42.7 \\
37.3,48.1\end{array}$ & $\begin{array}{l}47.4 \\
41.4,53.4\end{array}$ & $\begin{array}{l}44.6 \\
39.8,49.5\end{array}$ & $\begin{array}{l}44.2 \\
41.5,46.9\end{array}$ \\
\hline $\mathrm{MV}^{1}=3$ & M & $\begin{array}{l}20.7 \\
14.9,26.5\end{array}$ & $\begin{array}{l}19.9 \\
14.3,25.5\end{array}$ & $\begin{array}{l}22.9 \\
15.7,30.1\end{array}$ & $\begin{array}{l}25.6 \\
18.9,32.3\end{array}$ & $\begin{array}{l}22.1 \\
19.0,25.2\end{array}$ \\
\hline Eyesight problems & $\mathrm{F}$ & $\begin{array}{l}38.5 \\
33.3,43.6\end{array}$ & $\begin{array}{l}37.2 \\
31.8,42.5\end{array}$ & $\begin{array}{l}39.6 \\
33.7,45.5\end{array}$ & $\begin{array}{l}49.2 \\
44.3,54.2\end{array}$ & $\begin{array}{l}41.6 \\
38.9,44.2\end{array}$ \\
\hline$M V=3$ & M & $\begin{array}{l}30.7 \\
24.1,37.3\end{array}$ & $\begin{array}{l}31.1 \\
24.6,37.6\end{array}$ & $\begin{array}{l}36.6 \\
28.4,44.9\end{array}$ & $\begin{array}{l}46.4 \\
38.9,53.9\end{array}$ & $\begin{array}{l}35.8 \\
32.2,39.4\end{array}$ \\
\hline Hearing difficulty or deafness & $\mathrm{F}$ & $\begin{array}{l}8.5 \\
5.5,11.4\end{array}$ & $\begin{array}{l}8.7 \\
5.6,11.7\end{array}$ & $\begin{array}{l}11.3 \\
7.5,15.1\end{array}$ & $\begin{array}{l}19.1 \\
15.3,23.0\end{array}$ & $\begin{array}{l}12.2 \\
10.5,14.0\end{array}$ \\
\hline$M V=3$ & M & $\begin{array}{l}8.5 \\
4.5,12.4\end{array}$ & $\begin{array}{l}11.7 \\
7.2,16.2\end{array}$ & $\begin{array}{l}11.5 \\
6.0,17.0\end{array}$ & $\begin{array}{l}23.2 \\
16.8,29.6\end{array}$ & $\begin{array}{l}13.6 \\
11.0,16.2\end{array}$ \\
\hline Persistent cough & $\mathrm{F}$ & $\begin{array}{l}8.5 \\
5.5,11.4\end{array}$ & $\begin{array}{l}10.8 \\
7.4,14.2\end{array}$ & $\begin{array}{l}10.5 \\
6.8,14.2\end{array}$ & $\begin{array}{l}12.2 \\
9.0,15.4\end{array}$ & $\begin{array}{l}10.6 \\
8.9,12.2\end{array}$ \\
\hline$M V=3$ & M & $\begin{array}{l}10.6 \\
6.2,1.5\end{array}$ & $\begin{array}{l}7.1 \\
3.5,10.8\end{array}$ & $\begin{array}{l}9.2 \\
4.2,14.1\end{array}$ & $\begin{array}{l}12.6 \\
15.5,17.6\end{array}$ & $\begin{array}{l}9.9 \\
7.6,12.0\end{array}$ \\
\hline $\begin{array}{l}\text { Difficulty breathing, breathlessness or } \\
\text { asthma }\end{array}$ & $\mathrm{F}$ & $\begin{array}{l}8.7 \\
5.8,11.7\end{array}$ & $\begin{array}{l}9.3 \\
6.1,12.4\end{array}$ & $\begin{array}{l}9.8 \\
6.2,13.3\end{array}$ & $\begin{array}{l}12.0 \\
8.8,15.2\end{array}$ & $\begin{array}{l}10.0 \\
8.4,11.7\end{array}$ \\
\hline$M V=2$ & M & $\begin{array}{l}10.1 \\
5.8,14.3\end{array}$ & $\begin{array}{l}7.1 \\
3.5,10.8\end{array}$ & $\begin{array}{l}6.9 \\
2.5,11.2\end{array}$ & $\begin{array}{l}9.5 \\
5.1,13.9\end{array}$ & $\begin{array}{l}8.5 \\
6.4,10.6\end{array}$ \\
\hline Heart trouble or angina & $\mathrm{F}$ & $\begin{array}{l}5.0 \\
2.7,7.3\end{array}$ & $\begin{array}{l}5.9 \\
3.3,8.5\end{array}$ & $\begin{array}{l}3.4 \\
1.2,5.6\end{array}$ & $\begin{array}{l}4.8 \\
2.7,7.0\end{array}$ & $\begin{array}{l}4.8 \\
3.7,6.0\end{array}$ \\
\hline$M V=3$ & M & $\begin{array}{l}2.6 \\
0.4,4.9\end{array}$ & $\begin{array}{l}4.1 \\
1.3,6.9\end{array}$ & $\begin{array}{l}6.9 \\
2.5,11.2\end{array}$ & $\begin{array}{l}4.2 \\
1.1,7.2\end{array}$ & $\begin{array}{l}4.2 \\
2.7,5.8\end{array}$ \\
\hline Stomach or intestine problems & $\mathrm{F}$ & $\begin{array}{l}19.5 \\
15.3,23.7\end{array}$ & $\begin{array}{l}22.3 \\
17.7,26.9\end{array}$ & $\begin{array}{l}21.9 \\
16.9,26.9\end{array}$ & $\begin{array}{l}23.0 \\
18.8,27.2\end{array}$ & $\begin{array}{l}21.7 \\
19.5,23.9\end{array}$ \\
\hline$M V=4$ & M & $\begin{array}{l}12.7 \\
7.9,17.5\end{array}$ & $\begin{array}{l}16.8 \\
11.6,22.1\end{array}$ & $\begin{array}{l}13.7 \\
7.8,19.6\end{array}$ & $\begin{array}{l}14.9 \\
9.3,20.4\end{array}$ & $\begin{array}{l}14.6 \\
12.0,17.3\end{array}$ \\
\hline Faints or blackouts & $\mathrm{F}$ & $\begin{array}{l}3.5 \\
1.6,5.4\end{array}$ & $\begin{array}{l}2.8 \\
1.0,4.6\end{array}$ & $\begin{array}{l}3.8 \\
1.5,6.0\end{array}$ & $\begin{array}{l}5.9 \\
3.6,8.2\end{array}$ & $\begin{array}{l}4.1 \\
3.0,5.2\end{array}$ \\
\hline$M V=5$ & M & $\begin{array}{l}2.6 \\
0.4,4.9\end{array}$ & $\begin{array}{l}2.6 \\
0.3,4.8\end{array}$ & $\begin{array}{l}1.5 \\
0.0,3.6\end{array}$ & $\begin{array}{l}3.0 \\
0.4,5.6\end{array}$ & $\begin{array}{l}2.5 \\
1.3,3.7\end{array}$ \\
\hline $\begin{array}{l}\text { Paralysis, weakness or loss of one leg or } \\
\text { arm }\end{array}$ & $\mathrm{F}$ & $\begin{array}{l}3.2 \\
1.3,5.1\end{array}$ & $\begin{array}{l}3.7 \\
1.7,5.8\end{array}$ & $\begin{array}{l}1.9 \\
0.2,3.5\end{array}$ & $\begin{array}{l}10.1 \\
7.1,13.0\end{array}$ & $\begin{array}{l}5.1 \\
3.9,6.3\end{array}$ \\
\hline$M V=7$ & M & $\begin{array}{l}2.7 \\
0.4,5.0\end{array}$ & $\begin{array}{l}6.6 \\
3.1,10.1\end{array}$ & $\begin{array}{l}5.3 \\
1.5,9.2\end{array}$ & $\begin{array}{l}6.0 \\
2.4,9.5\end{array}$ & $\begin{array}{l}5.1 \\
3.5,6.8\end{array}$ \\
\hline $\begin{array}{l}\text { Skin disorders pressure sores, leg ulcers or } \\
\text { burns }\end{array}$ & $\mathrm{F}$ & $\begin{array}{l}1.7 \\
0.4,3.1\end{array}$ & $\begin{array}{l}0.6 \\
0.0,1.5\end{array}$ & $\begin{array}{l}1.9 \\
0.2,3.5\end{array}$ & $\begin{array}{l}4.3 \\
2.3,6.4\end{array}$ & $\begin{array}{l}2.3 \\
1.5,3.1\end{array}$ \\
\hline$M V=6$ & M & $\begin{array}{l}1.1 \\
0.0,2.5\end{array}$ & $\begin{array}{l}0.5 \\
0.0,1.5\end{array}$ & $\begin{array}{l}0.8 \\
0.0,2.3\end{array}$ & $\begin{array}{l}3.0 \\
0.4,5.5\end{array}$ & $\begin{array}{l}1.3 \\
0.5,2.2\end{array}$ \\
\hline $\begin{array}{l}\text { More than } 15 \text { disability days in the last } \\
\text { month }\end{array}$ & $\mathrm{F}$ & $\begin{array}{l}10.5 \\
7.2,13.7\end{array}$ & $\begin{array}{l}11.8 \\
8.3,15.3\end{array}$ & $\begin{array}{l}14.7 \\
10.4,18.9\end{array}$ & $\begin{array}{l}28.5 \\
24.0,33.0\end{array}$ & $\begin{array}{l}16.9 \\
14.9,19.0\end{array}$ \\
\hline$M V=5$ & M & $\begin{array}{l}9.0 \\
4.9,13.1\end{array}$ & $\begin{array}{l}13.2 \\
8.5,18.0\end{array}$ & $\begin{array}{l}11.5 \\
6.0,17.0\end{array}$ & $\begin{array}{l}17.2 \\
11.5,23.0\end{array}$ & $\begin{array}{l}12.7 \\
10.2,15.2\end{array}$ \\
\hline
\end{tabular}

1. $M V=$ missing values (men and women combined) 
Table 4: Comparison of Prevalence of Health Conditions Between Dominican Republic and Developed Country Settings, With Indirect Standardisation for Age and Sex

\begin{tabular}{|c|c|c|c|c|c|c|}
\hline Health condition & Criterion & $\begin{array}{l}\text { Prevalence (\%) in } \\
\text { Dominican Republic } \\
\text { sample }\end{array}$ & $\begin{array}{l}\text { Source of comparison } \\
\text { prevalence data }\end{array}$ & Standardised for & $\begin{array}{c}\text { Standardised morbidity } \\
\text { ratio }\end{array}$ & $\begin{array}{l}\text { 95\% confidence } \\
\text { intervals }\end{array}$ \\
\hline Diagnosed diabetes & $\begin{array}{l}\text { Told by a doctor that he/she has } \\
\text { diabetes }\end{array}$ & $14.0 \%$ & $\begin{array}{l}\text { NHANES 1999-2002, USA } \\
{[21]}\end{array}$ & $\begin{array}{l}\text { Sex, among those aged } \\
65 \text { and over }\end{array}$ & 88 & 73,107 \\
\hline Undiagnosed diabetes & $\begin{array}{l}\text { Never told by doctor that he/she } \\
\text { has diabetes, and fasting glucose } \\
>=7 \mathrm{mmol} / \mathrm{l}\end{array}$ & $3.5 \%$ & $\begin{array}{l}\text { NHANES 1999-2002, USA } \\
{[21]}\end{array}$ & $\begin{array}{l}\text { Sex, among those aged } \\
65 \text { and over }\end{array}$ & 65 & 45,92 \\
\hline Diabetes & $\begin{array}{l}\text { Diagnosed or undiagnosed } \\
\text { diabetes }\end{array}$ & $17.5 \%$ & $\begin{array}{l}\text { NHANES 1999-2002, USA } \\
{[21]}\end{array}$ & $\begin{array}{l}\text { Sex, among those aged } \\
65 \text { and over }\end{array}$ & 83 & 70,97 \\
\hline \multirow[t]{2}{*}{ Hypertension } & $\begin{array}{l}\text { Blood pressure }>=140 / 90 \text { or on } \\
\text { antihypertensive treatment }\end{array}$ & $73.8 \%$ & $\begin{array}{l}\text { NHANES 1999-2004, USA } \\
\text { [23] }\end{array}$ & $\begin{array}{l}\text { Sex, among those aged } \\
60 \text { and over }\end{array}$ & 108 & 101,117 \\
\hline & & & & Age $(60-69,70-79,80+)$ & 105 & 98,113 \\
\hline Metabolic syndrome & $\begin{array}{l}\text { NCEP - ATP III criteria, but those } \\
\text { diagnosed with diabetes } \\
\text { considered dysglycaemic and } \\
\text { those told they were hypertensive } \\
\text { considered hypertensive, } \\
\text { regardless of current control }\end{array}$ & $39.6 \%$ & $\begin{array}{l}\text { NHANES 1999-2002, USA } \\
\text { [22] }\end{array}$ & Age $(60-69,70+)$ and sex & 72 & 64,80 \\
\hline Stroke & $\begin{array}{l}\text { Told by a doctor that he/she has } \\
\text { had stroke }\end{array}$ & $8.7 \%$ & $\begin{array}{l}\text { NHANES 1999-2004, USA } \\
\text { [24] }\end{array}$ & Age $(65-74,75+)$ and sex & 100 & 81,123 \\
\hline Dementia & DSM-IV dementia & $5.4 \%$ & $\begin{array}{l}\text { EURODEM meta-analysis, } \\
\text { Europe [26] }\end{array}$ & $\begin{array}{l}\text { Age (five year bands) and } \\
\text { sex }\end{array}$ & 85 & 65,110 \\
\hline Anaemia & $\begin{array}{l}\text { WHO criteria - haemoglobin }<12 \\
\mathrm{~g} / \mathrm{dl} \text { in women, }<13 \mathrm{~g} / \mathrm{dl} \text { in men }\end{array}$ & $35.0 \%$ & $\begin{array}{l}\text { NHANES III, 1988-1994, } \\
\text { USA [25] }\end{array}$ & $\begin{array}{l}\text { Age }(65-74,75-84,85+) \\
\text { and sex }\end{array}$ & 310 & 262,373 \\
\hline
\end{tabular}


Table 5: Effects of Age, Sex and Socioeconomic Position on Diagnoses

\begin{tabular}{|c|c|c|c|}
\hline \multirow[b]{2}{*}{ Diagnoses } & \multicolumn{3}{|c|}{ Associations with diagnoses (prevalence ratios with $95 \%$ confidence intervals) } \\
\hline & Age, adjusted for sex & Sex, adjusted for age & $\begin{array}{l}\text { Socioeconomic position (quarters } \\
\text { of household assets), adjusted for } \\
\text { age and sex }\end{array}$ \\
\hline $\begin{array}{l}\text { Dementia } \\
\text { (10/66 criterion) }\end{array}$ & $\begin{array}{l}1.08 \\
1.07,1.10 \\
p<0.001\end{array}$ & $\begin{array}{l}0.89 \\
0.69,1.15 \\
p=0.38\end{array}$ & $\begin{array}{l}0.87 \\
0.77,0.97 \\
p=0.02\end{array}$ \\
\hline $\begin{array}{l}\text { Stroke } \\
\mathrm{MV}^{1}=6\end{array}$ & $\begin{array}{l}1.02 \\
1.00,1.04 \\
p=0.01\end{array}$ & $\begin{array}{l}1.45 \\
1.09,1.93 \\
p=0.01\end{array}$ & $\begin{array}{l}1.01 \\
0.88,1.16 \\
p=0.88\end{array}$ \\
\hline $\begin{array}{l}\text { Myocardial infarction } \\
\mathrm{MV}=35\end{array}$ & $\begin{array}{l}1.00 \\
0.96,1.03 \\
p=0.84\end{array}$ & $\begin{array}{l}0.77 \\
0.37,1.60 \\
p=0.49\end{array}$ & $\begin{array}{l}0.92 \\
0.66,1.27 \\
p=0.60\end{array}$ \\
\hline $\begin{array}{l}\text { Angina } \\
M V=25\end{array}$ & $\begin{array}{l}1.02 \\
0.96,1.07 \\
p=0.58\end{array}$ & $\begin{array}{l}0.92 \\
0.39,2.16 \\
p=0.86\end{array}$ & $\begin{array}{l}1.18 \\
0.79,1.76 \\
p=0.41\end{array}$ \\
\hline $\begin{array}{l}\text { Chronic obstructive pulmonary } \\
\text { disease } \\
M V=3\end{array}$ & $\begin{array}{l}1.01 \\
0.99,1.03 \\
p=0.47\end{array}$ & $\begin{array}{l}1.31 \\
0.93,1.84 \\
p=0.12\end{array}$ & $\begin{array}{l}0.84 \\
0.72,0.98 \\
p=0.02\end{array}$ \\
\hline $\begin{array}{l}\text { Hypertension (meets ISH criteria, and/ } \\
\text { or currently on treatment) } \\
\mathrm{MV}=13\end{array}$ & $\begin{array}{l}1.00 \\
1.00,1.01 \\
p=0.15\end{array}$ & $\begin{array}{l}0.92 \\
0.87,0.98 \\
p=0.006\end{array}$ & $\begin{array}{l}1.04 \\
1.01,1.07 \\
p=0.004\end{array}$ \\
\hline $\begin{array}{l}\text { Diabetes (self-reported diagnosis and/ } \\
\text { or blood glucose of }>7 \mathrm{mmol} / \mathrm{l} \text { ) }\end{array}$ & $\begin{array}{l}0.98 \\
0.96,0.99 \\
p=0.005\end{array}$ & $\begin{array}{l}0.84 \\
0.66,1.07 \\
p=0.15\end{array}$ & $\begin{array}{l}1.13 \\
1.01,1.26 \\
p=0.03\end{array}$ \\
\hline $\begin{array}{l}\text { Anaemia } \\
M V=10\end{array}$ & $\begin{array}{l}1.03 \\
1.02,1.03 \\
p<0.001\end{array}$ & $\begin{array}{l}1.16 \\
1.01,1.34 \\
p=0.04\end{array}$ & $\begin{array}{l}0.85 \\
0.79,0.91 \\
p<0.001\end{array}$ \\
\hline ICD-10 depression & $\begin{array}{l}1.02 \\
1.01,1.03 \\
p=0.003\end{array}$ & $\begin{array}{l}0.74 \\
0.58,0.95 \\
p=0.02\end{array}$ & $\begin{array}{l}0.70 \\
0.63,0.78 \\
p=<0.001\end{array}$ \\
\hline
\end{tabular}

1. MV = missing values

Nevertheless, among older people in the Dominican Republic this pattern of association was observed, but only for the more age-related and disabling conditions (dementia, anaemia, depression and most of the chronic limiting impairments). Conversely, cardiovascular risk factors (hypertension, diabetes, dyslipidaemia, obesity and the metabolic syndrome) were each associated with relative affluence, and there was no socioeconomic gradient for ischaemic heart disease or stroke. These findings are consistent with associations observed in a nationally representative survey of Thais aged 50 years and older, where poor self-rated health and functional limitation were associated with lower levels of education, income and wealth, but self-reported diagnoses of hypertension and heart disease were over-represented in the more affluent [31]. Urbanization may have important influences on the socioeconomic patterning of health; in the nationally representative Mexican Health and Ageing Study activity limitation was consistently associated with socioeconomic disadvantage in urban but not in rural areas [32]. In Buenos Aires, in a survey of adults of all ages, hypertension diagnosis was associated with low education and income in both sexes, as were obesity and high body mass index in women but not men [33]. In high income countries metabolic syndrome tends to be inversely associated with socioeconomic position in middle age; few studies have included older persons, but in the United States of America NHANES the effect of socioeconomic position was limited to women aged 2564 [34]. Little research has been conducted in countries with low and middle incomes, but our findings are consistent with reports from India of a higher prevalence of metabolic syndrome among better educated adolescents [35]. With regard to lifestyle risk factors, much more research has been conducted into associations between socioeconomic position and obesity, documenting the progress of the health transition in countries with low and middle incomes - obesity is no longer confined to the 
Table 6: Effects of Age, Sex and Socioeconomic Position on Impairments and Disability

\begin{tabular}{|c|c|c|c|}
\hline \multirow[t]{2}{*}{ Impairments and disability } & \multicolumn{3}{|c|}{$\begin{array}{l}\text { Associations with impairments and disability (prevalence ratios with } 95 \% \text { confidence } \\
\text { intervals) }\end{array}$} \\
\hline & Age, adjusted for sex & Sex, adjusted for age & $\begin{array}{l}\text { Socioeconomic position (quarters } \\
\text { of household assets), adjusted for } \\
\text { age and sex }\end{array}$ \\
\hline $\begin{array}{l}\text { Arthritis or rheumatism } \\
\mathrm{MV}^{1}=3\end{array}$ & $\begin{array}{l}1.00 \\
1.00,1.01 \\
p=0.23\end{array}$ & $\begin{array}{l}0.50 \\
0.43,0.59 \\
p<0.001\end{array}$ & $\begin{array}{l}0.98 \\
0.92,1.04 \\
p=0.47\end{array}$ \\
\hline $\begin{array}{l}\text { Eyesight problems } \\
\mathrm{MV}=3\end{array}$ & $\begin{array}{l}1.02 \\
1.01,1.02 \\
p<0.001\end{array}$ & $\begin{array}{l}0.88 \\
0.78,0.98 \\
p=0.02\end{array}$ & $\begin{array}{l}0.90 \\
0.85,0.95 \\
p<0.001\end{array}$ \\
\hline $\begin{array}{l}\text { Hearing difficulty or deafness } \\
M V=3\end{array}$ & $\begin{array}{l}1.06 \\
1.04,1.07 \\
p<0.001\end{array}$ & $\begin{array}{l}1.19 \\
0.94,1.49 \\
p=0.15\end{array}$ & $\begin{array}{l}0.91 \\
0.81,1.02 \\
p=0.10\end{array}$ \\
\hline $\begin{array}{l}\text { Persistent cough } \\
\mathrm{MV}=3\end{array}$ & $\begin{array}{l}1.02 \\
1.00,1.04 \\
p=0.02\end{array}$ & $\begin{array}{l}0.95 \\
0.72,1.24 \\
p=0.69\end{array}$ & $\begin{array}{l}0.86 \\
0.76,0.98 \\
p=0.02\end{array}$ \\
\hline $\begin{array}{l}\text { Difficulty breathing, breathlessness or } \\
\text { asthma } \\
\mathrm{MV}=2\end{array}$ & $\begin{array}{l}1.01 \\
0.99,1.03 \\
p=0.26\end{array}$ & $\begin{array}{l}0.85 \\
0.64,1.14 \\
p=0.28\end{array}$ & $\begin{array}{l}0.75 \\
0.66,0.86 \\
p<0.001\end{array}$ \\
\hline $\begin{array}{l}\text { Heart trouble or angina } \\
\mathrm{MV}=3\end{array}$ & $\begin{array}{l}1.00 \\
0.98,1.03 \\
p=0.98\end{array}$ & $\begin{array}{l}0.88 \\
0.57,1.35 \\
p=0.55\end{array}$ & $\begin{array}{l}0.81 \\
0.68,0.97 \\
p=0.02\end{array}$ \\
\hline $\begin{array}{l}\text { Stomach or intestine problems } \\
M V=4\end{array}$ & $\begin{array}{l}1.01 \\
1.00,1.02 \\
p=0.16\end{array}$ & $\begin{array}{l}0.68 \\
0.55,0.83 \\
p<0.001\end{array}$ & $\begin{array}{l}0.95 \\
0.87,1.04 \\
p=0.28\end{array}$ \\
\hline $\begin{array}{l}\text { Faints or blackouts } \\
M V=5\end{array}$ & $\begin{array}{l}1.02 \\
0.99,1.05 \\
p=0.14\end{array}$ & $\begin{array}{l}0.62 \\
0.36,1.06 \\
p=0.08\end{array}$ & $\begin{array}{l}0.73 \\
0.57,0.93 \\
p=0.01\end{array}$ \\
\hline $\begin{array}{l}\text { Paralysis, weakness or loss of one leg } \\
\text { or arm } \\
M V=7\end{array}$ & $\begin{array}{l}1.06 \\
1.03,1.08 \\
p<0.001\end{array}$ & $\begin{array}{l}1.07 \\
0.72,1.59 \\
p=0.72\end{array}$ & $\begin{array}{l}0.86 \\
0.71,1.03 \\
p=0.10\end{array}$ \\
\hline $\begin{array}{l}\text { Skin disorders pressure sores, leg } \\
\text { ulcers or burns } \\
M V=6\end{array}$ & $\begin{array}{l}1.06 \\
1.02,1.10 \\
p=0.001\end{array}$ & $\begin{array}{l}0.62 \\
0.30,1.31 \\
p=0.21\end{array}$ & $\begin{array}{l}0.58 \\
0.42,0.81 \\
p=0.001\end{array}$ \\
\hline $\begin{array}{l}\text { More than } 15 \text { disability days in the last } \\
\text { month } \\
M V=5\end{array}$ & $\begin{array}{l}1.05 \\
1.04,1.06 \\
p<0.001\end{array}$ & $\begin{array}{l}0.80 \\
0.63,1.00 \\
p=0.05\end{array}$ & $\begin{array}{l}0.89 \\
0.80,0.99 \\
p=0.03\end{array}$ \\
\hline
\end{tabular}

1. $M V=$ missing values

more affluent and inverse associations with socioeconomic position are increasingly observed, particularly for women living in countries with per capita GDP greater than $\$ 2500$ [36]. In Brazil, for example, there was a clear shift in the burden of obesity towards the poor between 1975 and 2003; the prevalence in women remained stable overall, but increased by $26 \%$ in the poorest two-fifths and decreased by $10 \%$ among the richest three-fifths [37]. The health transition is therefore likely to accentuate health inequalities. In the United States of America, reductions over the last 30 years in hypertension and dyslipidaemia have not lessened socioeconomic differences, and those for smoking and diabetes have increased due to less smoking in high income groups and increases in diabetes prevalence among those with low incomes [38]. The effect of the health transition on health inequalities may be particularly marked among older people. In the longitudinal American's Changing Lives Study [39], socioeconomic differences in health are modest in youth, increase markedly across middle age into young old age, and decline thereafter, a pattern observed consistently in developed country studies. There is evidence from the American's Changing Lives study that compression of morbidity (the increasing tendency for the preservation 


\begin{tabular}{|c|c|c|c|c|c|c|}
\hline \multirow[b]{2}{*}{ Risk factors } & \multirow[b]{2}{*}{ Sex } & \multicolumn{5}{|c|}{ Prevalence of risk factors by age and sex (\% with $95 \%$ confidence intervals) } \\
\hline & & $\begin{array}{l}65-69 \\
N=400^{1} \\
N=533^{2}\end{array}$ & $\begin{array}{l}70-74 \\
N=382^{1} \\
N=520^{2}\end{array}$ & $\begin{array}{l}75-79 \\
N=293^{1} \\
N=397^{2}\end{array}$ & $\begin{array}{l}80+ \\
N=408^{1} \\
N=561^{2}\end{array}$ & $\begin{array}{l}\text { All } \\
N=1483^{1} \\
N=2011^{2}\end{array}$ \\
\hline $\begin{array}{l}\text { Metabolic syndrome } \\
\text { (NCEP criteria) }\end{array}$ & $\mathrm{F}$ & $\begin{array}{l}38.2 \\
32.3,44.1\end{array}$ & $\begin{array}{l}46.3 \\
40.1,52.6\end{array}$ & $\begin{array}{l}37.3 \\
30.6,44.0\end{array}$ & $\begin{array}{l}35.7 \\
30.1,41.2\end{array}$ & $\begin{array}{l}39.3 \\
36.3,42.4\end{array}$ \\
\hline $\mathrm{MV}^{3}=30$ & M & $\begin{array}{l}23.3 \\
16.0,30.6\end{array}$ & $\begin{array}{l}26.2 \\
18.6,33.7\end{array}$ & $\begin{array}{l}15.3 \\
7.6,23.0\end{array}$ & $\begin{array}{l}15.5 \\
8.9,22.1\end{array}$ & $\begin{array}{l}20.7 \\
16.9,24.4\end{array}$ \\
\hline \multicolumn{7}{|l|}{ Metabolic syndrome components } \\
\hline Triglyceride $>150 \mathrm{mg} / \mathrm{dl}$ & $\mathrm{F}$ & $\begin{array}{l}24.5 \\
19.3,29.7\end{array}$ & $\begin{array}{l}24.5 \\
19.1,29.9\end{array}$ & $\begin{array}{l}14.4 \\
9.5,19.3\end{array}$ & $\begin{array}{l}19.4 \\
14.8,24.0\end{array}$ & $\begin{array}{l}21.0 \\
18.5,23.6\end{array}$ \\
\hline$M V=31$ & M & $\begin{array}{l}19.4 \\
12.5,26.2\end{array}$ & $\begin{array}{l}16.2 \\
9.8,22.5\end{array}$ & $\begin{array}{l}18.8 \\
10.5,27.1\end{array}$ & $\begin{array}{l}10.3 \\
4.8,15.9\end{array}$ & $\begin{array}{l}16.1 \\
12.7,19.4\end{array}$ \\
\hline Total cholesterol $>=5.2 \mathrm{mmol}$ & $\mathrm{F}$ & $\begin{array}{l}49.4 \\
43.4,55.5\end{array}$ & $\begin{array}{l}48.2 \\
41.9,54.5\end{array}$ & $\begin{array}{l}47.8 \\
40.8,54.7\end{array}$ & $\begin{array}{l}41.0 \\
35.3,46.7\end{array}$ & $\begin{array}{l}46.3 \\
43.2,49.5\end{array}$ \\
\hline $\mathrm{MV}=31$ & M & $\begin{array}{l}35.7 \\
27.4,43.9\end{array}$ & $\begin{array}{l}36.9 \\
28.6,45.2\end{array}$ & $\begin{array}{l}28.2 \\
18.7,37.8\end{array}$ & $\begin{array}{l}22.4 \\
14.8,30.0\end{array}$ & $\begin{array}{l}31.3 \\
27.0,35.6\end{array}$ \\
\hline $\begin{array}{l}\text { Waist circumference; Men > } 40 \text { inches, Women > } 35 \\
\text { inches }\end{array}$ & $\mathrm{F}$ & $\begin{array}{l}62.8 \\
57.0,68.7\end{array}$ & $\begin{array}{l}64.1 \\
58.0,70.2\end{array}$ & $\begin{array}{l}58.2 \\
51.3,65.0\end{array}$ & $\begin{array}{l}56.5 \\
50.8,62.3\end{array}$ & $\begin{array}{l}60.4 \\
57.4,63.4\end{array}$ \\
\hline$M V=25$ & M & $\begin{array}{l}19.4 \\
12.5,26.2\end{array}$ & $\begin{array}{l}20.0 \\
13.1,26.9\end{array}$ & $\begin{array}{l}18.8 \\
10.5,27.1\end{array}$ & $\begin{array}{l}23.3 \\
15.6,31.0\end{array}$ & $\begin{array}{l}20.4 \\
16.7,24.1\end{array}$ \\
\hline $\begin{array}{l}\text { Blood pressure } \\
>=130 / 85 \mathrm{mmHg}\end{array}$ & $\mathrm{F}$ & $\begin{array}{l}59.2 \\
53.2,65.1\end{array}$ & $\begin{array}{l}69.1 \\
63.3,74.9\end{array}$ & $\begin{array}{l}70.1 \\
63.8,76.5\end{array}$ & $\begin{array}{l}68.4 \\
63.0,73.9\end{array}$ & $\begin{array}{l}66.4 \\
63.5,69.4\end{array}$ \\
\hline$M V=20$ & M & $\begin{array}{l}71.9 \\
64.1,79.7\end{array}$ & $\begin{array}{l}77.7 \\
70.5,84.9\end{array}$ & $\begin{array}{l}64.7 \\
54.5,74.9\end{array}$ & $\begin{array}{l}67.2 \\
58.7,75.8\end{array}$ & $\begin{array}{l}71.0 \\
66.9,75.2\end{array}$ \\
\hline $\begin{array}{l}\text { Fasting glucose } \\
>110 \mathrm{mg} / \mathrm{dl}\end{array}$ & $\mathrm{F}$ & $\begin{array}{l}26.0 \\
20.6,31.3\end{array}$ & $\begin{array}{l}28.5 \\
22.8,34.1\end{array}$ & $\begin{array}{l}30.3 \\
24.0,36.7\end{array}$ & $\begin{array}{l}27.0 \\
21.7,32.1\end{array}$ & $\begin{array}{l}27.7 \\
24.9,30.5\end{array}$ \\
\hline$M V=32$ & M & $\begin{array}{l}28.1 \\
20.3,35.9\end{array}$ & $\begin{array}{l}27.7 \\
20.0,35.4\end{array}$ & $\begin{array}{l}27.1 \\
17.6,36.5\end{array}$ & $\begin{array}{l}18.1 \\
11.1,25.1\end{array}$ & $\begin{array}{l}25.3 \\
21.3,29.2\end{array}$ \\
\hline \multicolumn{7}{|l|}{ Other risk factors } \\
\hline Limited exercise (no walks of $>0.5 \mathrm{~km}$ in last month) & $\mathrm{F}$ & $\begin{array}{l}30.1 \\
25.2,35.0\end{array}$ & $\begin{array}{l}36.8 \\
31.5,42.1\end{array}$ & $\begin{array}{l}35.6 \\
29.8,41.4\end{array}$ & $\begin{array}{l}64.9 \\
60.1,69.7\end{array}$ & $\begin{array}{l}43.1 \\
40.4,45.8\end{array}$ \\
\hline$M V=12$ & M & $\begin{array}{l}17.6 \\
12.1,23.0\end{array}$ & $\begin{array}{l}24.5 \\
18.5,30.5\end{array}$ & $\begin{array}{l}27.3 \\
19.6,35.1\end{array}$ & $\begin{array}{l}35.9 \\
28.7,43.2\end{array}$ & $\begin{array}{l}25.9 \\
22.6,29.2\end{array}$ \\
\hline $\begin{array}{l}\text { Smoking } \\
\text { (> } 20 \text { pack years) }\end{array}$ & $\mathrm{F}$ & $\begin{array}{l}11.0 \\
7.6,14.4\end{array}$ & $\begin{array}{l}10.3 \\
6.8,13.8\end{array}$ & $\begin{array}{l}11.8 \\
7.8,15.7\end{array}$ & $\begin{array}{l}8.3 \\
5.5,11.1\end{array}$ & $\begin{array}{l}10.2 \\
8.5,11.9\end{array}$ \\
\hline $\mathrm{MV}=114$ & M & $\begin{array}{l}35.5 \\
28.6,42.4\end{array}$ & $\begin{array}{l}33.0 \\
26.3,39.7\end{array}$ & $\begin{array}{l}29.2 \\
21.0,37.3\end{array}$ & $\begin{array}{l}28.9 \\
21.9,35.9\end{array}$ & $\begin{array}{l}32.0 \\
28.4,35.6\end{array}$ \\
\hline
\end{tabular}

1. Sample size with blood tests

2. Total sample size

3. $M V=$ missing values (men and women combined) 
Table 8: Effects of Age, Sex and Socioeconomic Position on Risk Factors

\begin{tabular}{|c|c|c|c|}
\hline \multirow[b]{2}{*}{ Risk factors } & \multicolumn{3}{|c|}{ Associations with risk factors (prevalence ratios with $95 \%$ confidence intervals) } \\
\hline & Age, adjusted for sex & Sex, adjusted for age & $\begin{array}{l}\text { Socioeconomic position (quarters of } \\
\text { household assets), adjusted for age and sex }\end{array}$ \\
\hline 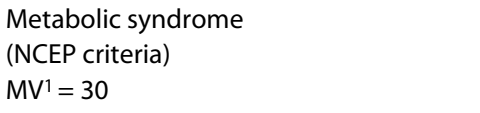 & $\begin{array}{l}0.93 \\
0.88,1.00 \\
P=0.04\end{array}$ & $\begin{array}{l}0.52 \\
0.43,0.63 \\
P<0.001\end{array}$ & $\begin{array}{l}1.17 \\
1.09,1.25 \\
P<0.001\end{array}$ \\
\hline \multicolumn{4}{|l|}{ Metabolic syndrome components } \\
\hline $\begin{array}{l}\text { Triglyceride }>150 \mathrm{mg} / \mathrm{dl} \\
\mathrm{MV}=31\end{array}$ & $\begin{array}{l}0.88 \\
0.81,0.96 \\
P=0.009\end{array}$ & $\begin{array}{l}0.76 \\
0.60,0.96 \\
P=0.02\end{array}$ & $\begin{array}{l}1.22 \\
1.10,1.35 \\
P<0.001\end{array}$ \\
\hline $\begin{array}{l}\text { Total cholesterol }>=5.2 \mathrm{mmol} \\
\mathrm{MV}=31\end{array}$ & $\begin{array}{l}0.93 \\
0.88,0.97 \\
P=0.002\end{array}$ & $\begin{array}{l}0.67 \\
0.58,0.78 \\
P<0.001\end{array}$ & $\begin{array}{l}1.09 \\
1.02,1.16 \\
P=0.007\end{array}$ \\
\hline $\begin{array}{l}\text { Waist circumference; Men }>40 \text { inches, } \\
\text { Women }>35 \text { inches MV }=25\end{array}$ & $\begin{array}{l}0.97 \\
0.93,1.01 \\
P=0.14\end{array}$ & $\begin{array}{l}0.33 \\
0.27,0.40 \\
P<0.001\end{array}$ & $\begin{array}{l}1.11 \\
1.06,1.17 \\
P<0.001\end{array}$ \\
\hline $\begin{array}{l}\text { Blood pressure } \\
>=130 / 85 \mathrm{mmHg} \\
\mathrm{MV}=20\end{array}$ & $\begin{array}{l}1.01 \\
0.98,1.05 \\
P=0.35\end{array}$ & $\begin{array}{l}1.07 \\
0.99,1.15 \\
P=0.07\end{array}$ & $\begin{array}{l}1.01 \\
0.97,1.04 \\
P=0.74\end{array}$ \\
\hline $\begin{array}{l}\text { Fasting glucose } \\
>110 \mathrm{mg} / \mathrm{dl} \\
\mathrm{MV}=32\end{array}$ & $\begin{array}{l}0.97 \\
0.90,1.04 \\
P=0.49\end{array}$ & $\begin{array}{l}0.91 \\
0.76,1.09 \\
P=0.31\end{array}$ & $\begin{array}{l}1.14 \\
1.04,1.24 \\
P=0.03\end{array}$ \\
\hline \multicolumn{4}{|l|}{ Other risk factors } \\
\hline $\begin{array}{l}\text { Limited exercise (no walks of }>0.5 \mathrm{~km} \text { in } \\
\text { last month) } \\
\mathrm{MV}=12\end{array}$ & $\begin{array}{l}1.16 \\
1.13,1.20 \\
P<0.001\end{array}$ & $\begin{array}{l}0.78 \\
0.73,0.83 \\
P<0.001\end{array}$ & $\begin{array}{l}1.00 \\
0.97,1.03 \\
P=0.96\end{array}$ \\
\hline $\begin{array}{l}\text { Smoking } \\
\text { (> } 20 \text { pack years) } \\
M V=114\end{array}$ & $\begin{array}{l}0.93 \\
0.86,1.01 \\
P=0.08\end{array}$ & $\begin{array}{l}3.10 \\
2.54,3.78 \\
P<0.001\end{array}$ & $\begin{array}{l}0.94 \\
0.86,1.03 \\
P=0.20\end{array}$ \\
\hline
\end{tabular}

1. MV = missing values

of health and functioning into late old age) is mainly observed in the most educated, and that this effect is becoming more pronounced over time.

\section{Conclusions}

The prevalence of many chronic diseases and chronic disease risk factors is already nearly as high in low socioeconomic status neighbourhoods in Santo Domingo, Dominican Republic as in the USA. Cautious extrapolation from our cross-sectional data suggests that the overall prevalence of conditions that are strongly ageassociated (dementia, stroke and arthritis) is likely to rise in coming years with continued demographic ageing. There is also scope for increases in the prevalence of those cardiovascular risk factors currently associated with relative affluence (diabetes, hypertension, dyslipi- daemia, obesity and the metabolic syndrome), if, as has been observed in other settings undergoing the epidemiologic transition, these exposures begin to be concentrated instead among the more numerous economically disadvantaged sectors of the population. This scenario would threaten both an increase in the overall incidence and prevalence of cardiovascular diseases, and in the extent of health inequalities. It will be important to monitor the actual extent and direction of such trends with further epidemiological research, in particular to assess the effectiveness and equity of attempts to improve the prevention and control of chronic diseases. The generally poor health of older women in the Dominican Republic should be a matter of public health concern, and a focus for prevention activities. Controlling for age, women were likelier than men to be hypertensive, dyslipidaemic, 


\begin{tabular}{|c|c|c|c|c|c|c|c|c|}
\hline \multirow{3}{*}{$\begin{array}{l}\text { Outcome } \\
\text { Exposure }\end{array}$} & \multirow[b]{3}{*}{$\begin{array}{l}\text { Number and } \\
\text { proportion (\%) } \\
\text { exposed }\end{array}$} & \multicolumn{3}{|c|}{ WHODAS II disability score } & \multicolumn{4}{|c|}{15 or more disability days } \\
\hline & & \multirow[t]{2}{*}{$\begin{array}{l}\text { Median score in } \\
\text { the exposed } \\
\text { group } \\
\text { (interquartile } \\
\text { range) }\end{array}$} & \multicolumn{2}{|c|}{$\begin{array}{l}\text { Independent associations between } \\
\text { diagnoses and impairments and } \\
\text { WHODAS II score } 1\end{array}$} & \multirow[t]{2}{*}{$\begin{array}{l}\text { Proportion }(\%) \text { with } \\
15 \text { or more disability } \\
\text { days- in the exposed } \\
\text { group }\end{array}$} & \multicolumn{3}{|c|}{$\begin{array}{l}\text { Independent associations between diagnoses } \\
\text { and impairments and } 15 \text { or more disability } \\
\text { days } 2\end{array}$} \\
\hline & & & $\mathbf{R R}$ & $\begin{array}{l}\mathbf{9 5 \%} \text { confidence } \\
\text { intervals }\end{array}$ & & PR & $\begin{array}{l}95 \% \text { confidence } \\
\text { intervals }\end{array}$ & $\begin{array}{l}\text { Population attributable } \\
\text { prevalence fraction }\end{array}$ \\
\hline \multicolumn{9}{|l|}{ Diagnoses } \\
\hline $\begin{array}{l}\text { Dementia } \\
\text { (10/66 criterion) }\end{array}$ & $235(11.7 \%)$ & $27.8(8.3-58.3)$ & 1.57 & $1.40,1.77$ & $79 / 235(33.6 \%)$ & 1.50 & $1.16,1.95$ & $10.5 \%$ \\
\hline Stroke & $175(8.7 \%)$ & $27.8(8.3-57.6)$ & 1.37 & $1.21,1.55$ & $65 / 175(37.1 \%)$ & 1.46 & $1.12,1.91$ & $6.5 \%$ \\
\hline Myocardial infarction & $35(1.7 \%)$ & $19.4(5.6-38.9)$ & 0.90 & $0.74,1.09$ & $7 / 35(20.0 \%)$ & 0.82 & $0.42,1.61$ & \\
\hline Angina & $25(1.2 \%)$ & $22.2(1.4-44.4)$ & 1.23 & $0.88,1.73$ & $8 / 25(32.0 \%)$ & 1.50 & $0.87,2.57$ & $0.8 \%$ \\
\hline Hypertension & $1516(75.4 \%)$ & $8.3(0.0-27.8)$ & 1.00 & $0.90,1.11$ & $245 / 1515(16.2 \%)$ & 1.06 & $0.81,1.38$ & $5.7 \%$ \\
\hline $\begin{array}{l}\text { Chronic obstructive pulmonary } \\
\text { disease }\end{array}$ & $137(6.8 \%)$ & $22.2(5.6-41.7)$ & 1.02 & $0.90,1.16$ & $36 / 137(26.3 \%)$ & 1.18 & $0.85,1.64$ & $1.6 \%$ \\
\hline Diabetes $^{3}$ & $260(17.5 \%)$ & $13.9(0.0-30.6)$ & 1.07 & $0.96,1.19$ & $48 / 260(18.5 \%)$ & 0.92 & $0.68,1.26$ & Inverse association \\
\hline Anaemia $^{3}$ & $515(35.0 \%)$ & $13.9(0.0-35.4)$ & 1.16 & $1.06,1.27$ & $20 / 84(23.8 \%)$ & 1.53 & $1.16,2.02$ & $17.1 \%$ \\
\hline ICD-10 depression & $278(13.8 \%)$ & $33.3(16.7-50.0)$ & 1.43 & $1.30,1.57$ & $91 / 278(32.7 \%)$ & 1.48 & $1.16,1.90$ & $9.4 \%$ \\
\hline \multicolumn{9}{|l|}{ Impairments } \\
\hline Arthritis or rheumatism & 737 (36.7\%) & $19.4(5.6-33.3)$ & 1.34 & $1.23,1.46$ & $167 / 736(22.7 \%)$ & 1.68 & $1.35,2.10$ & $22.5 \%$ \\
\hline Eyesight problems & $796(39.6 \%)$ & $19.4(5.6-36.1)$ & 1.13 & $1.04,1.23$ & $153 / 795(19.2 \%)$ & 1.01 & $0.81,1.27$ & $1.8 \%$ \\
\hline Hearing difficulty or deafness & $255(12.7 \%)$ & $25.0(5.6-43.7)$ & 1.17 & $1.05,1.30$ & $60 / 255(23.5 \%)$ & 1.10 & $0.80,1.72$ & $0.9 \%$ \\
\hline Persistent cough & $207(10.3 \%)$ & $19.4(5.6-41.7)$ & 1.01 & $0.90,1.13$ & $55 / 206(26.7 \%)$ & 1.11 & $0.83,1.47$ & $2.0 \%$ \\
\hline $\begin{array}{l}\text { Difficulty breathing, } \\
\text { breathlessness or asthma }\end{array}$ & $191(9.5 \%)$ & $30.6(11.1-47.2)$ & 1.12 & $1.00,1.27$ & $60 / 190(31.6 \%)$ & 1.19 & $0.88,1.60$ & $2.8 \%$ \\
\hline Heart trouble or angina & $93(4.6 \%)$ & $27.8(11.1-40.9)$ & 1.11 & $0.96,1.30$ & $26 / 93(28.0 \%)$ & 1.17 & $0.79,1.71$ & $0.9 \%$ \\
\hline Stomach or intestine problems & $388(19.3 \%)$ & $25.0(8.3-44.4)$ & 1.27 & $1.16,1.39$ & $103 / 388(26.5 \%)$ & 1.33 & $1.04,1.71$ & $8.9 \%$ \\
\hline
\end{tabular}


Table 9: Independent Associations Between Diagnoses and Impairments, and Disability (Continued)

\begin{tabular}{|c|c|c|c|c|c|c|c|c|}
\hline Faints or blackouts & $71(3.5 \%)$ & $33.3(18.1-56.3)$ & 1.30 & $1.10,1.53$ & $29 / 71(40.8 \%)$ & 1.25 & $0.82,1.92$ & $1.5 \%$ \\
\hline $\begin{array}{l}\text { Paralysis, weakness or loss of } \\
\text { one leg or arm }\end{array}$ & $102(5.1 \%)$ & $50.0(27.8-69.4)$ & 1.88 & $1.67,2.12$ & $60 / 102(58.8 \%)$ & 2.50 & $1.92,3.25$ & $11.8 \%$ \\
\hline $\begin{array}{l}\text { Skin disorders (pressure sores, } \\
\text { leg ulcers or burns) }\end{array}$ & 39 (1.9\%) & $50.0(27.8-69.4)$ & 1.70 & $1.40,2.08$ & 21/39 (53.8\%) & 2.43 & $1.57,3.77$ & $4.3 \%$ \\
\hline
\end{tabular}

1 Zero-inflated negative binomial regression, adjusted for all other diagnoses and impairments other than diabetes and anaemia. $\mathrm{N}=1975$ (see also footnote 3 2 Poisson regression

3 Parameters for diabetes and anaemia were obtained from a separate model restricted to those participants who had provided a blood sample 
obese and underactive and had a higher prevalence of the metabolic syndrome, depression, physical impairments and severe disability. More research into the prevalence and causes of anaemia in older people is indicated, and the government should consider evaluating screening and treatment programmes. Finally, more attention should be given to the social protection of older people, including income security and provision and financing of long term care [40].

\section{Abbreviations}

AGECAT: Automated Geriatric Examination for Computer Assisted Taxonomy CSI'D': Community Screening Instrument for Dementia; CERAD: Consortium to Establish a Registry for Alzheimer's Disease; DSM-IV: Diagnostic and Statistical Manual of Mental Disorders, 4th. Edition; ICD-10 International Classification of Diseases $10^{\text {th }}$ revision; WHODAS 2.0: World Health Organization Disability Assessment Schedule; NHANES: National Health and Nutrition Examination Survey

\section{Competing interests}

The 10/66 Dementia Research Group works closely with Alzheimer's Disease International (ADI), the non-profit federation of 77 Alzheimer associations around the world. ADI is committed to strengthening Alzheimer associations worldwide, raising awareness regarding dementia and Alzheimer's Disease and advocating for more and better services for people with dementia and their caregivers. ADI is supported in part by grants from GlaxoSmithKline, Novartis, Lundbeck, Pfizer and Eisai. Daisy Acosta is currently the Chair of ADI.

\section{Authors' contributions}

All of the authors worked collectively to develop the protocols and methods described in this paper. MJP led the research group and CPF acted as research coordinator. DA was the principal investigator responsible for the field work in the Dominican Republic. MJP wrote the first draft with the assistance of DA and $R R$. These three authors also conducted the analyses. Other authors reviewed the manuscript, provided further contributions and suggestions. All authors read and approved the final manuscript.

\section{Acknowledgements}

The 10/66 Dementia Research Group's research has been funded by the Wellcome Trust Health Consequences of Population Change Programme (GR066133 - Prevalence phase in Cuba and Brazil; GR08002- Incidence phase in Peru, Mexico, Argentina, Cuba, Dominican Republic, Venezuela and China), the World Health Organisation (India, Dominican Republic and China), the US Alzheimer's Association (IIRG - 04 - 1286 - Peru, Mexico and Argentina), and FONDACIT (Venezuela). The Rockefeller Foundation supported our recent dissemination meeting at their Bellagio Centre. None of the sponsors or funders of this study had any involvement in this publication.

\section{Author Details}

IInternal Medicine Department, Geriatric Section, Universidad Nacional Pedro Henriquez Ureña (UNPHU), John F Kennedy Avenue, Santo Domingo, Dominican Republic, ${ }^{2}$ Centre Hospitalier, Universitaire de Butare, Butare, Rwanda, ${ }^{3}$ Ministerio De Salud Pública y Asistencia Social Dirección Área VI De Salud, Calle \#28, esquina \#39, Ensanche La Fé, Santo Domingo, Dominican Republic, ${ }^{4}$ Laboratorio Nacional Dr Defilló, Calle Santo Thomás de Aquino \#1, Santo Domingo, Dominican Republic and ${ }^{5}$ Health Service and Population Research Department, Institute of Psychiatry P060, De Crespigny Park, London SE5 8AF, UK

Received: 11 January 2010 Accepted: 16 June 2010 Published: 16 June 2010

\section{References}

1. Fuster $V$, Voute J: MDGs: chronic diseases are not on the agenda. Lancet 2005, 366:1512-1514.

2. Yusuf S, Reddy S, Ounpuu S, Anand S: Global burden of cardiovascular diseases: part I: general considerations, the epidemiologic transition, risk factors, and impact of urbanization. [Review] [44 refs]. Circulation 2001, 104:2746-2753.

3. Yusuf S, Hawken S, Ounpuu S, Dans T, Avezum A, Lanas F, McQueen M, Budaj A, Pais P, Varigos J, Lisheng L, INTERHEART S: I: Effect of potentially modifiable risk factors associated with myocardial infarction in 52 countries (the INTERHEART study): case-control study.[see comment]. Lancet 2004, 364:937-952.

4. Hofman K, Ryce A, Prudhomme W, Kotzin S: Reporting of noncommunicable disease research in low-and middle-income countries: a pilot bibliometric analysis. J Med Libr Assoc 2006, 94:415-420.

5. World Health Organization: WHO Statistical Information System. Working paper describing data sources, methods and results for projections of mortality and burden of disease for 2005, 2015 and 2030. 2006.

6. Horton R: The neglected epidemic of chronic disease. Lancet 2005, 366:1514.

7. Horton R: Chronic diseases: the case for urgent global action. Lancet 2007, 370:1881-1882.

8. Schargrodsky H, Hernandez-Hernandez R, Champagne BM, Silva H, Vinueza R, Silva Aycaguer LC, Touboul PJ, Boissonnet CP, Escobedo J Pellegrini F, Macchia A, Wilson E: CARMELA: assessment of cardiovascular risk in seven Latin American cities. Am J Med 2008, 121:58-65.

9. $\mathrm{Ng} \mathrm{N}$, Van MH, Tesfaye F, Bonita R, Byass $P$, Stenlund $H$, Weinehall $L$, Wall S: Combining risk factors and demographic surveillance: potentials of WHO STEPS and INDEPTH methodologies for assessing epidemiological transition. Scand J Public Health 2006, 34:199-208.

10. Deepa M, Pradeepa R, Rema M, Mohan A, Deepa R, Shanthirani S, Mohan $V$ : The Chennai Urban Rural Epidemiology Study (CURES)--study design and methodology (urban component) (CURES-I). J Assoc Physicians India 2003, 51:863-870.

11. Prince $M$, Ferri CP, Acosta D, Albanese E, Arizaga R, Dewey M, Gavrilova SI, Guerra M, Huang $Y$, Jacob KS, Krishnamoorthy ES, McKeigue $P$, Rodrigues JL, Salas A, Sosa AL, Sousa R, Stewart R, Uwakwe R: The protocols for the 10/66 Dementia Research Group population-based research programme. BMC Public Health 2007, 7:165.

12. Central Intelligence Agency: The World Factbook -- Dominican Republic. Washington DC, USA, CIA; 2008. 31-1-2008.

13. Llibre Rodriguez JJ, Ferri CP, Acosta D, Guerra M, Huang Y, Jacob KS, Krishnamoorthy ES, Salas A, Sosa AL, Acosta I, Dewey ME, Gaona C, Jotheeswaran AT, Li S, Rodriguez D, Rodriguez G, Kumar PS, Valhuerdi A, Prince M: Prevalence of dementia in Latin America, India, and China: a population-based cross-sectional survey. Lancet 2008, 372:464-474.

14. Copeland JRM, Dewey ME, Griffith-Jones HM: A computerised psychiatric diagnostic system and case nomenclature for elderly subjects: GMS and AGECAT. Psychological Medicine 1986, 16:89-99.

15. Hall KS, Hendrie HH, Brittain HM, Norton JA, Rodgers DD, Prince CS, Pillay N, Blue AW, Kaufert JN, Nath A, Shelton P, Postl BD, Osuntokun BO: The development of a dementia screeing interview in two distinct languages. International Journal of Methods in Psychiatric Research 1993, 3:1-28.

16. Ganguli M, Chandra V, Gilbey J: Cognitive test performance in a community-based non demented elderly sample in rural India: the Indo-US cross national dementia epidemiology study. International Psychogeriatrics 1996, 8:507-524.

17. Prince $M$, Acosta $D$, Chiu H, Scazufca M, Varghese $M$ : Dementia diagnosis in developing countries: a cross-cultural validation study. Lancet 2003, 361:909-917.

18. American Psychiatric Association: Diagnostic and Statistical Manual of Mental Disorders 4th edition. Washington DC: AMA; 1994.

19. George LK, Fillenbaum GG: OARS methodology: A decade of experience in geriatric assessment. Journal of the American Geriatrics Society 1985, 33:607-615.

20. Rehm J, Ustun TB, Saxena S: On the development and psychometric testing of the WHO screening instrument to assess disablement in the general population. International Journal of Methods in Psychiatric Research 2000, 8:110-122.

21. Cowie CC, Rust KF, Byrd-Holt DD, Eberhardt MS, Flegal KM, Engelgau MM, Saydah SH, Williams DE, Geiss LS, Gregg EW: Prevalence of diabetes and impaired fasting glucose in adults in the U.S. population: National Health And Nutrition Examination Survey 1999-2002. Diabetes Care 2006, 29:1263-1268. 
22. Ford ES: Prevalence of the metabolic syndrome defined by the International Diabetes Federation among adults in the U.S. Diabetes Care 2005, 28:2745-2749.

23. Ostchega Y, Dillon CF, Hughes JP, Carroll M, Yoon S: Trends in hypertension prevalence, awareness, treatment, and control in older U.S. adults: data from the National Health and Nutrition Examination Survey 1988 to 2004. J Am Geriatr Soc 2007, 55:1056-1065.

24. National Heart LaBI: Morbidity \& Mortality: 2007 Chart Book on Cardiovascular, Lung, and Blood Diseases. U.S. Department of Health and Human Services - National Institutes of Health; 2007.

25. Guralnik JM, Eisenstaedt RS, Ferrucci L, Klein HG, Woodman RC: Prevalence of anemia in persons 65 years and older in the United States: evidence for a high rate of unexplained anemia. Blood 2004, 104:2263-2268.

26. Lobo A, Launer LJ, Fratiglioni L, Andersen K, Di Carlo A, Breteler MM: Prevalence of dementia and major subtypes in Europe: A collaborative study of population-based cohorts. Neurologic Diseases in the Elderly Research Group. Neurology 2000, 54:S4-S9.

27. Acosta D, Rottbeck R, Rodriguez G, Ferri CP, Prince MJ: The epidemiology of dependency among urban-dwelling older people in the Dominican Republic; a cross-sectional survey. BMC Public Health 2008, 8:285.

28. Prince $M, A$ costa $D$, Albanese $E$, Arizaga R, Ferri CP, Guerra M, Huang $Y$, Jacob KS, Jimenez-Velazquez IZ, Rodriguez IL, Salas A, Sosa AL, Sousa R, Uwakwe R, van der PR, Williams J, Wortmann M: Ageing and dementia in low and middle income countries-Using research to engage with public and policy makers. Int Rev Psychiatry 2008, 20:332-343.

29. Ong KL, Cheung BM, Man YB, Lau CP, Lam KS: Prevalence, awareness, treatment, and control of hypertension among United States adults 1999-2004. Hypertension 2007, 49:69-75.

30. Regitz-Zagrosek V, Lehmkuhl E, Mahmoodzadeh S: Gender aspects of the role of the metabolic syndrome as a risk factor for cardiovascular disease. Gend Med 2007, 4(Suppl B):S162-S177.

31. Zimmer Z, Amornsirisomboon P: Socioeconomic status and health among older adults in Thailand: an examination using multiple indicators. Soc Sci Med 2001, 52:1297-1311.

32. Smith KV, Goldman N: Socioeconomic differences in health among older adults in Mexico. Soc Sci Med 2007, 65:1372-1385.

33. Fleischer NL, ez Roux AV, Alazraqui M, Spinelli H: Social patterning of chronic disease risk factors in a Latin American city. J Urban Health 2008, 85:923-937.

34. Loucks EB, Magnusson KT, Cook S, Rehkopf DH, Ford ES, Berkman LF: Socioeconomic position and the metabolic syndrome in early, middle, and late life: evidence from NHANES 1999-2002. Ann Epidemiol 2007, 17:782-790.

35. Singh R, Bhansali A, Sialy R, Aggarwal A: Prevalence of metabolic syndrome in adolescents from a north Indian population. Diabet Med 2007, 24:195-199.

36. Monteiro CA, Moura EC, Conde WL, Popkin BM: Socioeconomic status and obesity in adult populations of developing countries: a review. Bull World Health Organ 2004, 82:940-946.

37. Monteiro CA, Conde WL, Popkin BM: Income-specific trends in obesity in Brazil: 1975-2003. Am J Public Health 2007, 97:1808-1812.

38. Kanjilal S, Gregg EW, Cheng YJ, Zhang P, Nelson DE, Mensah G, Beckles GL: Socioeconomic status and trends in disparities in 4 major risk factors for cardiovascular disease among US adults, 1971-2002. Arch Intern Med 2006, 166:2348-2355.

39. House JS, Lantz PM, Herd P: Continuity and change in the social stratification of aging and health over the life course: evidence from a nationally representative longitudinal study from 1986 to 2001/2002 (Americans' Changing Lives Study). J Gerontol B Psychol Sci Soc Sci 2005, 60(Spec No 2): 15-26.

40. World Health Organization: Towards an International Consensus on Policy for Long-Term Care of the Ageing. Geneva, World Health Organization; 2000.

Pre-publication history

The pre-publication history for this paper can be accessed here:

http://www.biomedcentral.com/1471-2458/10/344/prepub doi: $10.1186 / 1471-2458-10-344$

Cite this article as: Acosta et al., The prevalence and social patterning of chronic diseases among older people in a population undergoing health transition. A 10/66 Group cross-sectional population-based survey in the Dominican Republic BMC Public Health 2010, 10:344

\section{Submit your next manuscript to BioMed Central and take full advantage of:}

- Convenient online submission

- Thorough peer review

- No space constraints or color figure charges

- Immediate publication on acceptance

- Inclusion in PubMed, CAS, Scopus and Google Scholar

- Research which is freely available for redistribution

Submit your manuscript at www.biomedcentral.com/submit
C BioMed Central 